Article

\title{
Biomonitoring of Trace Elements in Hair of Schoolchildren Living Near a Hazardous Waste Incinerator-A 20 Years Follow-Up
}

\author{
Roser Esplugas $^{1}$, Montse Mari ${ }^{2} \oplus$, Montse Marquès ${ }^{1}$, Marta Schuhmacher ${ }^{2} \mathbb{D}$, José L. Domingo ${ }^{1}$ \\ and Martí Nadal ${ }^{1, *(1)}$ \\ 1 Laboratory of Toxicology and Environmental Health, School of Medicine, IISPV, Universitat Rovira i Virgili, \\ 43201 Reus, Catalonia, Spain; roser.esplugas@urv.cat (R.E.); montserrat.marques@urv.cat (M.M.); \\ joseluis.domingo@urv.cat (J.L.D.) \\ 2 Environmental Engineering Laboratory, Departament d'Enginyeria Quimica, Universitat Rovira i Virgili, \\ 43007 Tarragona, Catalonia, Spain; montserrat.mari@urv.cat (M.M.); marta.schuhmacher@urv.cat (M.S.) \\ * Correspondence: marti.nadal@urv.cat; Tel.: +34-977-758-930
}

Received: 26 August 2019; Accepted: 27 September 2019; Published: 1 October 2019

\begin{abstract}
Since 1998, a monitoring program is periodically performed to assess the environmental and human health impact of air chemicals potentially emitted by a hazardous waste incinerator (HWI) located in Constantí (Catalonia, Spain). In 2017, samples of hair were collected from 94 schoolchildren (aged 10-13 years) living nearby and the levels of 11 trace elements (As, $\mathrm{Be}, \mathrm{Cd}, \mathrm{Cr}, \mathrm{Hg}, \mathrm{Mn}, \mathrm{Ni}, \mathrm{Pb}$, $\mathrm{Sn}, \mathrm{Tl}$ and $\mathrm{V}$ ) were determined. The concentrations showed the following descending order: $\mathrm{Pb}>\mathrm{Hg}$ $>\mathrm{Ni}>\mathrm{Sn}>\mathrm{Mn}>\mathrm{Cr}$. In turn, As, Be and $\mathrm{Tl}$ were not detected, while $\mathrm{Cd}$ and V were found only in a few samples. Some metal levels were significantly, positively correlated. Some significant differences were also noticed according to the gender and the specific zone of residence. Finally, the levels of trace elements showed fluctuations through time. $\mathrm{Cr}$ and $\mathrm{Pb}$ showed a significant decrease in comparison to the concentrations obtained in the baseline study (1998). According to the current results, metal emissions from the HWI are not relevant in terms of human health impact since their levels were similar and even lower than those reported in other contaminated areas.
\end{abstract}

Keywords: Trace elements; hair; children; hazardous waste incinerator; Constantí (Catalonia, Spain)

\section{Introduction}

To date, there is only a hazardous waste incinerator (HWI) in Spain, which is located in Constantí (Tarragona County, Catalonia). Being built in 1996-1998, it started to operate in 1999. At the building time, a large pre-operational monitoring program was initiated, not only as an additional measure of environmental control but also responding to the demands of residents and public authorities. The study was focused on two chemicals of special concern: polychlorinated dibenzo- $p$-dioxins and dibenzofurans (PCDD/Fs) as well as metals and metalloids. One of the main goals of this program was aimed at assuring that the facility would not be a relevant source of environmental pollution and its operations should not affect the health of the population living nearby. The initial surveillance program was designed to evaluate the impact on the environment, through the monitoring of soil and vegetation [1,2], while the impact on the residents was assessed through the monitoring of biological tissues such as blood, breast milk and hair [3-8]. Furthermore, the dietary intake of PCDD/Fs and metals by the local population was also evaluated $[9,10]$.

The location of this HWI, which is situated near a chemical/petrochemical industrial complex, a municipal waste incinerator and in a zone with heavy traffic, can mean additional toxic emissions. Considering that there exist many emission sources in the area, the environmental surveillance of 
metals and metalloids is clearly a need for public health. The non-occupationally population is exposed to trace elements mainly through the diet including water [11], being inhalation and transdermal absorption minor exposure pathways [12]. The effects of a chronic/acute exposure to trace elements are varied, including cancer (e.g., arsenic [As], cadmium [Cd], chromium [Cr], nickel [Ni]), skin lesions (e.g., As, beryllium [Be], tin [Sn]), neurological disorders (e.g., mercury [Hg], manganese [Mn], thallium [Tl]), learning disability (e.g., lead [Pb]) or respiratory problems (e.g., vanadium [V]) among others [13-17]. Furthermore, it should be taking to account that the synergistic effect of the co-exposure to different metals and metalloids can also lead to cumulative adverse health effects $[18,19]$.

The monitoring program has been continuously conducted since 1999. While information of the environmental levels of pollutants has been quite recurrent in the last 20 years [20], data on the concentrations of trace elements in the same biomonitors (i.e., hair, blood and autopsy tissues) have been updated every $4-5$ years [21-24].

Despite the traditional approach for human biomonitoring is based on the analysis of blood and urine, human hair is also a very useful and valuable biological matrix [25]. The levels of metals in hair are up to 10-fold higher than those usually found in blood or urine [26]. The concentrations of heavy metals in hair can be modulated by endogenous factors including metabolic pathways, as well as exogenous impregnations such as air pollutants [27]. More interestingly, hair samples allow an easy sampling and storage, being a non-invasive method.

The biomonitoring of children is more complex than that of adults. However, results are undoubtedly of great interest [28], as children are more susceptible to metal exposure, since they have higher absorption rates in relation to their body weight. Moreover, they have low capacity of detoxification and excretion, as well as behavioural patterns that the environmental pollution can potentially affect more easily [29,30].

Being part of a large biological surveillance program, this study was aimed at identifying whether there are any health risks for the population living close to the HWI. More specifically, the purpose of the present study was to measure the concentration of $\mathrm{As}, \mathrm{Be}, \mathrm{Cd}, \mathrm{Cr}, \mathrm{Hg}, \mathrm{Mn}, \mathrm{Ni}, \mathrm{Pb}, \mathrm{Sn}, \mathrm{Tl}$ and $\mathrm{V}$ in hair of schoolchildren who live near the facility. A detailed analysis of the correlation between metals and the differences according to the sex and specific zones of residence was also carried out. Furthermore, temporal trends were determined by comparing these data with those of previous surveys.

\section{Materials and Methods}

\subsection{Sample Collection}

Between June and September of 2017, hair samples were obtained from 94 schoolchildren (44 boys and 50 girls aged $10-13$ years). About $2-3 \mathrm{~cm}$ of hair was cut from an area close to the occipital region of the scalp. Only naturally coloured hair was selected in order to avoid biased results. The participants were classified in 3 groups according to the area of residence: (1) urban (named as downtown), (2) close to an important chemical/petrochemical complex (named as $\mathrm{CH} / \mathrm{PCH}$ complex) and (3) near a large oil refinery, the HWI and a municipal incinerator (named as refinery/HWI/MI) (Figure 1). A consent form according to the declaration of Helsinki was signed by the tutors of each participant. The study protocol, 07/2017, was reviewed and approved by the Ethical Committee for Human Studies of the Pere Virgili Health Research Institute (IISPV), Reus/Tarragona, Spain in March 30, 2017 [22,23]. 


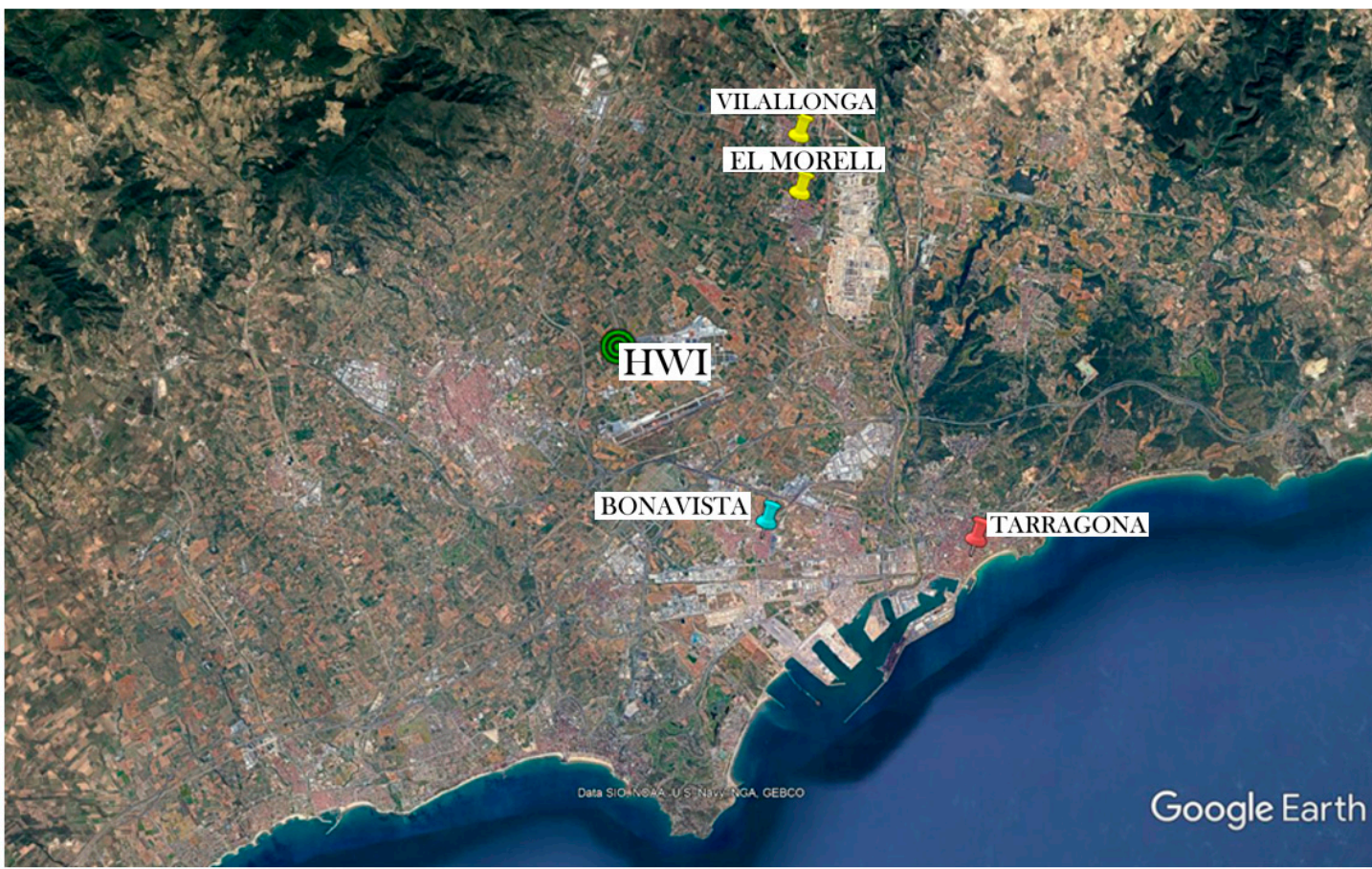

Urban

$\mathrm{CH} / \mathrm{PCH}$ complex

refinery/HWI/MI

Figure 1. Sampling area.

\subsection{Pre-treatment and Chemical Analysis}

Hair samples were washed with 1\% Triton X-100 (E. Merck, Darmstadt, Germany) in an ultrasounds bath for 20 minutes in order to remove external contamination. Then, the soap was removed with distilled water and samples were 3 times-washed with Milli-Q water. Around $150 \mathrm{mg}$ of sample were placed in hermetic Teflon bombs and digested with $2 \mathrm{~mL}$ of $65 \%$ nitric acid (Suprapur, E. Merck, Darmstadt, Germany) for 12 hours at $110^{\circ} \mathrm{C}$. Samples were then filtered, diluted to $10 \mathrm{~mL}$ of Milli-Q water and stored at $-20^{\circ} \mathrm{C}$.

The concentrations of $\mathrm{As}, \mathrm{Be}, \mathrm{Cd}, \mathrm{Cr}, \mathrm{Hg}, \mathrm{Mn}, \mathrm{Ni}, \mathrm{Pb}, \mathrm{Sn}, \mathrm{Tl}$ and $\mathrm{V}$ in hair samples were analysed according to previous studies conducted in our laboratory [6,31-33] using inductively coupled plasma-mass spectrometry (ICP-MS, Perkin Elmer Elan 6000). Each sample was tested by duplicate, being Lobster Hepatopancreas employed as quality control (NRC Canada, TORT-2) every 5 samples. Blanks used during the digestion were also run every 5 samples. The limits of detection (LODs) were $0.03 \mu \mathrm{g} / \mathrm{g}$ for Be, Cd, Pb and Tl; $0.07 \mu \mathrm{g} / \mathrm{g}$ for As, Cr, Mn, Ni, Sn and V; and $0.13 \mu \mathrm{g} / \mathrm{g}$ for $\mathrm{Hg}$.

\subsection{Statistical Analysis}

All data were analysed by using the statistical package SPSS 25.0. Values with a Z-score above 2.5 and under -2.5 were considered as outliers. In addition, a visual inspection of the boxplot was also conducted to verify these outliers. Non-detected levels of metals were assumed as to be one-half of the respective LOD (ND = $1 / 2$ LOD). Only trace elements with values $70 \%$ (or more) above the LOD were considered for further statistical evaluation. To assess the distribution of the values, the Kolmogorov-Smirnov test was used. Correlations between metal concentrations were performed employing the Spearman correlation coefficient. The Student's t-test was used to compare differences of metal levels between boys and girls. In turn, ANOVA and subsequent T3 Dunnett's post-hoc tests were employed to assess differences between groups according to the zones of residence and the significance in the temporal evolution. The level of statistical significance was established at $p<0.05$. 


\section{Results}

The concentrations of the 11 analysed elements in 94 samples of hair from schoolchildren living in Tarragona County are shown in Table 1 . Arsenic, Be and Tl were not detected, whereas Cd and V were only detected in 37 and 23 samples, respectively. In previous campaigns of the monitoring program, traces of $\mathrm{Cd}$ and $\mathrm{V}$ were only found in very few samples of hair [6,31-33]. Although the information relative to these elements is shown, they are excluded from the statistical analysis.

Table 1. Metal concentrations ( $\mu \mathrm{g} / \mathrm{g}$ ) in hair of 94 school children living in Tarragona County (2017).

\begin{tabular}{ccccccc}
\hline Metal & Mean \pm SD & Median & Recovery (\%) & Interquartile Range & LOD & Maximum \\
\hline $\mathrm{As}$ & $\mathrm{ND}$ & - & 81.6 & - & 0.07 & \\
$\mathrm{Be}$ & $\mathrm{ND}$ & - & 42.3 & - & 0.03 & \\
$\mathrm{Cd}$ & $0.04 \pm 0.05$ & 0.02 & 85.0 & 0.02 & 0.03 & 0.44 \\
$\mathrm{Cr}$ & $0.14 \pm 0.05$ & 0.13 & 92.3 & 0.00 & 0.07 & 0.44 \\
$\mathrm{Hg}$ & $0.73 \pm 0.56$ & 0.59 & 86.9 & 0.62 & 0.13 & 2.70 \\
$\mathrm{Mn}$ & $0.30 \pm 0.16$ & 0.25 & 86.4 & 0.23 & 0.07 & 0.77 \\
$\mathrm{Ni}$ & $0.54 \pm 0.53$ & 0.36 & 73.3 & 0.48 & 0.07 & 2.66 \\
$\mathrm{~Pb}$ & $1.44 \pm 1.89$ & 0.93 & 73.9 & 1.52 & 0.03 & 11.86 \\
$\mathrm{Sn}$ & $0.41 \pm 0.34$ & 0.32 & 47.1 & 0.42 & 0.07 & 1.64 \\
$\mathrm{Tl}$ & $\mathrm{ND}$ & $\mathrm{ND}$ & 88.9 & - & 0.03 & - \\
$\mathrm{V}$ & $0.07 \pm 0.08$ & 0.07 & 104.2 & 0.16 & 0.07 & 0.43 \\
\hline
\end{tabular}

$\mathrm{ND}=$ not detected, $\mathrm{LOD}=$ limit of detection. Data are given as mean $\pm \mathrm{SD}$.

Lead presented the highest mean concentration $(1.44 \mu \mathrm{g} / \mathrm{g})$, ranging from undetected values to $11.9 \mu \mathrm{g} / \mathrm{g}$. Mercury also presented relatively high levels, with a mean and a range of 0.73 and $0.13-2.70 \mu \mathrm{g} / \mathrm{g}$, respectively. The mean concentrations of Sn, Mn and Cr were $0.41,0.30$ and $0.14 \mu \mathrm{g} / \mathrm{g}$, respectively. Finally, $\mathrm{Cd}$ and $\mathrm{V}$ were detected only in a few samples. Both metals exhibited the lowest concentrations ( 0.04 and $0.07 \mu \mathrm{g} / \mathrm{g}$, respectively). When evaluating the correlation between metal levels (Table 2), a weak but significant positive correlation, was found between $\mathrm{Mn}$ and $\mathrm{Ni}, \mathrm{Pb}(p<0.01)$ and Sn $(p<0.05)$ and also between $\mathrm{Ni}$ and both $\mathrm{Cr}$ and $\mathrm{Sn}(p<0.01)$.

Table 2. Correlations between metal concentrations in hair of 94 schoolchildren living in Tarragona County (2017).

\begin{tabular}{cccccccc}
\hline Metal & $\mathbf{C r}$ & $\mathbf{H g}$ & $\mathbf{M n}$ & $\mathbf{N i}$ & $\mathbf{P b}$ & $\mathbf{S n}$ & $\mathbf{V}$ \\
\hline $\mathrm{Cd}$ & 0.085 & 0.028 & 0.261 & 0.345 & 0.533 & 0.375 & 0.181 \\
$\mathrm{Cr}$ & & 0.061 & 0.177 & $0.271^{* *}$ & 0.198 & 0.091 & 0.180 \\
$\mathrm{Hg}$ & & & -0.057 & -0.130 & 0.077 & 0.047 & 0.164 \\
$\mathrm{Mn}$ & & & & $0.405^{* *}$ & $0.291^{* *}$ & $0.234^{*}$ & 0.128 \\
$\mathrm{Ni}$ & & & & & 0.158 & $0.299^{* *}$ & 0.286 \\
$\mathrm{~Pb}$ & & & & & & 0.158 & 0.106 \\
$\mathrm{Sn}$ & & & & & & & 0.268 \\
\hline
\end{tabular}

Spearman correlation coefficient (r) is shown. ${ }^{*}$ and ${ }^{* *}$ means significant differences at $p<0.05$ and $p<0.01$ (bilateral), respectively.

When metal concentrations were assessed according to the sex of the schoolchildren, significant differences were found in the levels of $\mathrm{Hg}, \mathrm{Ni}, \mathrm{Pb}$ and $\mathrm{Sn}$ (Figure 2). Thus, girls exhibited significant lower levels of $\mathrm{Hg}(0.61 \mu \mathrm{g} / \mathrm{g}$ vs. $0.88 \mu \mathrm{g} / \mathrm{g},(p<0.05))$ and $\mathrm{Pb}(1.03 \mu \mathrm{g} / \mathrm{g}$ vs. $1.89 \mu \mathrm{g} / \mathrm{g}, p<0.05)$ and significant higher concentrations of $\mathrm{Ni}(0.69 \mu \mathrm{g} / \mathrm{g}$ vs. $0.36 \mu \mathrm{g} / \mathrm{g}, p<0.01)$ and $\mathrm{Sn}(0.54 \mu \mathrm{g} / \mathrm{g}$ vs. $0.28 \mu \mathrm{g} / \mathrm{g}, p<0.001)$ than boys. Finally, $\mathrm{Cd}, \mathrm{Cr}$ and $\mathrm{Mn}$ did not show significant differences between girls and boys. 
$\mathrm{Cr}$

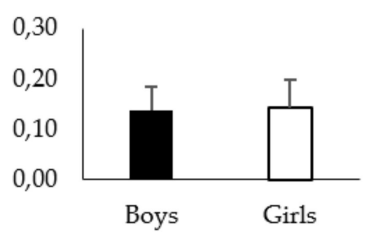

$\mathrm{Ni}$

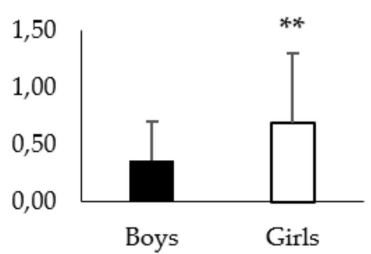

$\mathrm{Hg}$

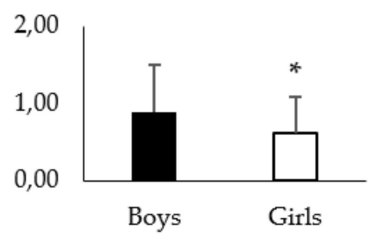

$\mathrm{Pb}$

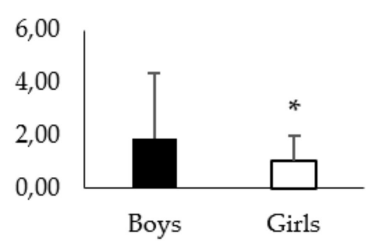

$\mathrm{Mn}$

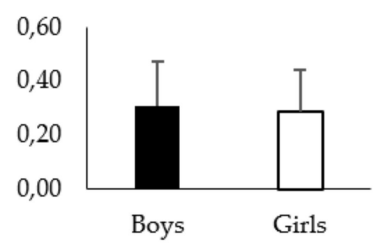

$\mathrm{Sn}$

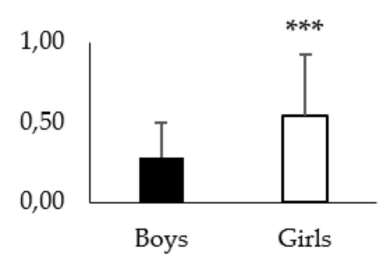

Figure 2. Metal concentrations $(\mu \mathrm{g} / \mathrm{g})$ in hair of schoolboys $(n=44)$ and girls $(n=50)$ living in Tarragona County (2017). Data are given as mean \pm SD. Statistics: non-parametric t-test. Significant differences between both groups at: ${ }^{*} p<0.05,{ }^{* *} p<0.01$ and ${ }^{* *} p<0.001$.

Mercury was identified as the only element showing significant differences in the levels in hair according to the specific zones of residence (Table 3). Significantly higher concentrations of $\mathrm{Hg}$ were found in the children living in Tarragona downtown with respect to those living in the remaining two evaluated areas $(p<0.01)$, both of them with industrial characteristics.

Table 3. Metal concentrations $(\mu \mathrm{g} / \mathrm{g})$ in hair of school children living in Tarragona County according to the specific zones of residence (2017).

\begin{tabular}{cccc}
\hline Metal & Downtown & CH/PCH Complex & Refinery/HWI/MI \\
\hline $\mathrm{As}$ & $\mathrm{ND}$ & $\mathrm{ND}$ & $\mathrm{ND}$ \\
$\mathrm{Be}$ & $\mathrm{ND}$ & $\mathrm{ND}$ & $\mathrm{ND}$ \\
$\mathrm{Cd}$ & $0.03 \pm 0.03$ & $0.04 \pm 0.09$ & $0.04 \pm 0.03$ \\
$\mathrm{Cr}$ & $0.14 \pm 0.05$ & $0.15 \pm 0.07$ & $0.13 \pm 0.03$ \\
$\mathrm{Hg}$ & $1.07 \pm 0.64^{\mathrm{a}}$ & $0.54 \pm 0.45^{\mathrm{b}}$ & $0.56 \pm 0.40^{\mathrm{b}}$ \\
$\mathrm{Mn}$ & $0.26 \pm 0.15$ & $0.29 \pm 0.20$ & $0.33 \pm 0.15$ \\
$\mathrm{Ni}$ & $0.42 \pm 0.41$ & $0.55 \pm 0.61$ & $0.63 \pm 0.56$ \\
$\mathrm{~Pb}$ & $1.08 \pm 0.85$ & $1.55 \pm 2.93$ & $1.73 \pm 1.82$ \\
$\mathrm{Sn}$ & $0.47 \pm 0.37$ & $0.27 \pm 0.26$ & $0.44 \pm 0.34$ \\
$\mathrm{Tl}$ & $\mathrm{ND}$ & $\mathrm{ND}$ & $\mathrm{ND}$ \\
$\mathrm{V}$ & $0.10 \pm 0.10$ & $0.07 \pm 0.08$ & $0.04 \pm 0.03$ \\
\hline
\end{tabular}

$\mathrm{ND}=$ not detected. Data are given as mean \pm SD. Statistics: ANOVA and T3 Dunnett's post-hoc test. Data not showing a common superscript $(\mathrm{a}, \mathrm{b}, \mathrm{c})$ indicate significant differences between zones (downtown, $\mathrm{CH} / \mathrm{PCH}$ complex and refinery/HWI/MI) at $p<0.05$.

The temporal trends of metal concentrations in hair of schoolchildren are summarized in Table 4 . The results of the current study are compared with those of previous surveys, including the baseline study (1998) and the intermediate campaigns (2002, 2007 and 2012). A significant decrease of Cd in recent years was noted when compared to the baseline results $(p<0.001)$. Chromium levels significantly increased in 2007 and 2012 in comparison to previous years $(p<0.001)$ but the concentration of this element notably decreased in $2017(p<0.001)$, being this reduction significant in contrast to the previous surveys. Despite Ni concentrations were significantly lower in $2002(p<0.001)$, they have remained nearly constant through time. Furthermore, although $\mathrm{Pb}$ concentrations decreased significantly after the baseline survey $(p<0.001)$, in 2017 they raised again, being significantly higher than those observed in 2007 and $2012(p<0.01)$. Tin showed significantly lower concentrations in the period 2002-2012 $(p<0.001)$, while current values are comparable to those found in 1998. Mercury was the only element which did not exhibit significant differences between surveys. Finally, V was found at relatively low 
concentrations, being detected in only 23 samples in 2017 but contrasting with data from previous surveys, where it was never detected.

Table 4. Metal concentrations $(\mu \mathrm{g} / \mathrm{g})$ in hair of school children living in Tarragona County obtained in the studies conducted in 1998, 2002, 2007, 2012 and 2017.

\begin{tabular}{|c|c|c|c|c|c|}
\hline Metal & 1998 & 2002 & 2007 & 2012 & 2017 \\
\hline As & ND & ND & ND & ND & ND \\
\hline $\mathrm{Be}$ & ND & ND & ND & ND & ND \\
\hline $\mathrm{Cd}$ & $0.18 \pm 0.14^{\mathrm{a}}$ & ND & $0.02 \pm 0.01^{b}$ & $0.02 \pm 0.01^{b}$ & $0.04 \pm 0.05$ \\
\hline $\mathrm{Cr}$ & $0.36 \pm 0.52^{\mathrm{a}}$ & $0.37 \pm 0.21^{\mathrm{a}}$ & $1.31 \pm 1.14^{b}$ & $0.98 \pm 0.22^{b}$ & $0.14 \pm 0.05^{\mathrm{c}}$ \\
\hline $\mathrm{Hg}$ & $0.67 \pm 0.42$ & $0.70 \pm 0.45$ & $0.56 \pm 0.53$ & $0.58 \pm 0.23$ & $0.73 \pm 0.56$ \\
\hline Mn & $0.26 \pm 0.17^{\mathrm{ac}}$ & $0.16 \pm 0.23^{b}$ & $0.21 \pm 0.24 \mathrm{ab}$ & $0.20 \pm 0.23^{b}$ & $0.30 \pm 0.16^{c}$ \\
\hline $\mathrm{Ni}$ & $0.65 \pm 0.54^{\mathrm{a}}$ & $0.27 \pm 0.22^{b}$ & $0.48 \pm 0.58^{\mathrm{a}}$ & $0.53 \pm 0.73^{\mathrm{a}}$ & $0.54 \pm 0.53^{a}$ \\
\hline $\mathbf{P b}$ & $5.81 \pm 3.86^{\mathrm{a}}$ & $0.86 \pm 2.02^{b c}$ & $0.58 \pm 0.68^{b}$ & $0.63 \pm 0.78^{b}$ & $1.44 \pm 1.89^{\mathrm{C}}$ \\
\hline Sn & $0.37 \pm 0.45^{\mathrm{a}}$ & $0.13 \pm 0.10^{b}$ & $0.16 \pm 0.18^{b}$ & $0.20 \pm 0.29^{b}$ & $0.41 \pm 0.34^{a}$ \\
\hline $\mathrm{Tl}$ & ND & ND & ND & ND & ND \\
\hline $\mathbf{V}$ & ND & ND & ND & ND & $0.07 \pm 0.08$ \\
\hline
\end{tabular}

$\mathrm{ND}=$ not detected. Data are given as mean \pm SD. Statistics: ANOVA and T3 Dunnett's post-hoc test. Data not showing a common superscript $\left({ }^{a}, b, c\right)$ indicate significant differences between years $(1998,2002,2007,2012$ and 2017) at $p<0.05$.

\section{Discussion}

Some metals were significantly and positively correlated: $\mathrm{Mn}$ with $\mathrm{Ni}, \mathrm{Pb}$ and $\mathrm{Sn}$ and also $\mathrm{Ni}$ with $\mathrm{Cr}$ and $\mathrm{Sn}$. This kind of correlations has been previously reported in the scientific literature. In Russia, Semenova et al. [34] also found a positive correlation between $\mathrm{Pb}$ and $\mathrm{Mn}$ in hair of children living in the vicinity of abandoned mines in the South Urals, while Drobyshev et al. [35] reported positive correlations of $\mathrm{Al}, \mathrm{Cu}, \mathrm{Fe}, \mathrm{Ni}$ and $\mathrm{V}$, when analysing the concentrations of trace elements in children (aged 7-9) of St. Petersburg.

The body growth, physiology, the presence of specific sexual hormones and metabolizing enzymes, along with lifestyle and physical activity contribute to exhibit differences in the accumulation and excretion processes of metals between boys and girls [36]. Sex can play a role, being suggested that females are more vulnerable to exposure to trace metals than males, particularly at higher levels of exposure [37]. Some authors have even reported higher concentrations of trace elements in hair of girls than in boys [14,38]. In agreement with these findings, girls living in Tarragona County showed significantly higher levels of $\mathrm{Ni}$ and $\mathrm{Sn}$ than boys. However, $\mathrm{Hg}$ and $\mathrm{Pb}$ were found at lower levels in girls, when compared to boys. Further research is required to better understanding the sex differences in metal levels in hair, especially highlighting if changes can be applied to all the trace elements or there exist variabilities among metals.

It has been largely described that the profile of hair metal composition depends on local environmental conditions [39]. When we analysed the differences in metal levels between zones of residence, it was observed that children living in Tarragona downtown presented higher levels of $\mathrm{Hg}$ than those living near the $\mathrm{CH} / \mathrm{PCH}$ complex or near the refinery/HWI/MI. Since the environmental concentrations of $\mathrm{Hg}$ are not increased in this area according to data from soils and vegetation [40,41], traffic could be even more important than the industrial activity, in terms of $\mathrm{Hg}$ exposure. However, it must be remarked that dietary intake plays a key role in human exposure to metals. Food consumption is the most contributive pathway of exposure to metals and metalloids [42]. As suggested by Castaño et al. [15], the relationship between the zone of residence and $\mathrm{Hg}$ concentrations could be attributed to the nutritional habits of children, which are invariably different according to their socio-economic status.

The temporal profile of metal concentrations in hair of schoolchildren has revealed some interesting findings. Thus, the significant reduction of $\mathrm{Pb}$ since 1998 may be attributed to their removal from gasoline, as this element -as an additive- was banned in 2001. In fact, the benefits of this legislative 
measure, in terms of environmental pollution by $\mathrm{Pb}$, have been largely observed [43]. However, an accurate assessment of the temporal trends of metal concentrations in hair should be conducted also using data from other biological tissues, which are not currently available. Furthermore, changes in the dietary habits of the population living in Tarragona County should be also considered. In 2012, an increase in the dietary exposure to $\mathrm{Hg}$ and $\mathrm{Cr}$ was reported [44]. In turn, a spectacular decrease in the intake of both elements occurred recently (unpublished data), which was also found for PCDD/Fs [45].

The concentrations of trace elements in hair of schoolchildren were compared with those of recent studies found in the scientific literature (Table 5). Most of these investigations are focused on areas with important industrial or mining activities or even in urban zones $[11,14,26,30,34-37,46,47]$. The different results might be attributed to the differences among the respective geographical areas. Furthermore, despite the mean $\mathrm{Cr}$ concentration is similar to most levels found in recent literature, $\mathrm{Cr}$ concentrations in the urban area of Madrid were approximately 5-fold higher than those of the present study [46]. The mean level of $\mathrm{Hg}$ was also higher than the concentrations found in other locations, such as toxic waste disposal sites of Russia [35] and different urban areas [14,47]. In contrast, $\mathrm{Hg}$ concentrations in children from Tarragona County were lower than those found in other Spanish studies focused on assessing urban and industrial/mining areas [26,46]. The current Mn values were lower than elsewhere, differing notably from those found in Sardinia (Italy) and Russia [34,35,37]. In contrast, higher Ni levels were found when our data are compared with those of other studies, excepting those reported by Xie et al. [30] in Shaoguan Guangdong (China) and Evrenoglou et al. [14] in Athens (Greece). In turn, $\mathrm{Pb}$ levels were higher than those found in hair of children living in some mining, volcanic, sub-urban and urban areas $[14,26,34,36,47]$ but lower than values from children living near certain mining zones, as well as near to toxic waste disposal sites and cement plants $[11,30,34,35,37]$. The individual characteristics of the geographic areas where the children live would probably be the responsible of the observed variability in $\mathrm{Ni}$ and $\mathrm{Pb}$ levels among studies.

Thus, the trace element levels obtained in our study, which are similar and even lower than those reported in other contaminated areas, suggest that metal emissions from the HWI are not relevant in terms of human health impact. Nevertheless, additional studies in combination with information from other biological tissues, as well as the dietary intake of metals, are clearly needed for a complete identification of potential health risks. 
Table 5. Summary of recently published metal concentrations $(\mu \mathrm{g} / \mathrm{g})$ in hair of children in different countries.

\begin{tabular}{|c|c|c|c|c|c|c|c|c|c|c|c|c|c|c|c|}
\hline City, Country & Zone & $\begin{array}{c}\text { Age } \\
\text { (years) }\end{array}$ & Sex & As & Be & $\mathrm{Cd}$ & $\mathrm{Cr}$ & $\mathrm{Hg}$ & Mn & $\mathrm{Ni}$ & $\mathrm{Pb}$ & Sn & $\mathrm{Tl}$ & $\mathrm{v}$ & Reference \\
\hline $\begin{array}{l}\text { Constantí, Tarragona, } \\
\text { Spain }\end{array}$ & HWI, industrial, urban & $7-13$ & Both & $\mathrm{ND}$ & ND & 0.04 & 0.14 & 0.73 & 0.30 & 0.54 & 1.44 & 0.41 & ND & 0.07 & Present study \\
\hline Karabash, Russia * & copper smelter & 14 & Both & 0.06 & & 0.07 & 0.16 & & 0.72 & 0.21 & 1.96 & & & & Skalny et al. [11] \\
\hline Varna, Russia * & control locations & 14 & Both & 0.06 & & 0.04 & 0.26 & & 0.53 & 0.23 & 1.43 & & & & Skalny et al. [11] \\
\hline Tomino, Russia * & control locations & 14 & Both & 2.04 & & 0.12 & 0.14 & & 0.60 & 0.30 & 5.44 & & & & Skalny et al. [11] \\
\hline Kifisia Athens, Greece & urban & $11-12$ & Both & 0.031 & & 0.03 & & 0.49 & & 0.92 & 1.36 & & & & Evrenoglou et al. [14] \\
\hline $\begin{array}{l}\text { Philadelphia, Athens, } \\
\text { Greece }\end{array}$ & urban & $11-12$ & Both & 0.035 & & 0.03 & & 0.52 & & 1.38 & 3.31 & & & & Evrenoglou et al. [14] \\
\hline Kryoneri, Athens, Greece & sub-urban & $11-12$ & Both & 0.026 & & 0.03 & & 0.36 & & 0.62 & 0.80 & & & & Evrenoglou et al. [14] \\
\hline Huelva, Spain & $\begin{array}{c}\text { living near } \\
\text { industrial/mining areas }\end{array}$ & $6-9$ & Both & 0.07 & & $<0.003$ & & 1.28 & 0.26 & & $<0.09$ & & & & Molina-Villalba et al. [26] \\
\hline $\begin{array}{l}\text { Shaoguan Guangdong, } \\
\text { Tielong, China }\end{array}$ & $\begin{array}{l}\text { cement plant and } \\
\text { ex-mining area }\end{array}$ & $\leq 15$ & Both & 1.13 & & 0.19 & 0.17 & & & 1.21 & 10.88 & & & & Xie et al. [30] \\
\hline $\begin{array}{l}\text { Rural settlements Tubinsk, } \\
\text { Russia }\end{array}$ & $\begin{array}{l}\text { vicinity of abandoned } \\
\text { mines in South Urals }\end{array}$ & $7-14$ & Both & & & 0.05 & & & 1.43 & 0.24 & 2.74 & & & & Semenova et al. [34] \\
\hline Ishmurzino, Russia & $\begin{array}{l}\text { vicinity of abandoned } \\
\text { mines in South Urals }\end{array}$ & $7-14$ & Both & & & 0.30 & & & 1.21 & 0.30 & 1.97 & & & & Semenova et al. [34] \\
\hline Semenovsk, Russia & $\begin{array}{l}\text { vicinity of abandoned } \\
\text { mines in South Urals }\end{array}$ & $7-14$ & Both & & & 0.03 & & & 2.38 & 0.45 & 0.91 & & & & Semenova et al. [34] \\
\hline $\begin{array}{l}\text { Leningradskaya Oblast,' } \\
\text { St. Petersburg, Russia }\end{array}$ & $\begin{array}{c}\text { controls from a non-urban } \\
\text { settlement }\end{array}$ & $7-9$ & Both & 0.04 & & 0.16 & 0.25 & 0.22 & 3.41 & 0.42 & 2.51 & & & 0.05 & Drobyshev et al. [35] \\
\hline $\begin{array}{l}\text { Leningradskaya Oblast,' } \\
\text { St. Petersburg, Russia }\end{array}$ & $\begin{array}{l}\text { proximity to the toxic } \\
\text { waste disposal grounds }\end{array}$ & $7-9$ & Both & 0.03 & & 0.14 & 0.31 & 0.14 & 2.93 & 0.39 & 3.82 & & & 0.05 & Drobyshev et al. [35] \\
\hline Pace del Mela, Sicily *\# & industrial & $11-14$ & Both & 0.03 & & 0.01 & 0.10 & & 0.40 & 0.10 & 0.80 & & & 0.10 & Tamburo et al. [36] \\
\hline $\begin{array}{l}\text { Gela, Butera and Niscemi, } \\
\text { Sicily *\# }\end{array}$ & polymetallic mining area & $11-14$ & Both & 0.04 & & 0.02 & 0.10 & & 0.20 & 0.10 & 0.40 & & & & Tamburo et al. [36] \\
\hline Palermo, Sicily *\# & urban & $11-14$ & Both & 0.0003 & & 0.02 & 0.20 & & 0.20 & 0.04 & 0.80 & & & 0.10 & Tamburo et al. [36] \\
\hline $\begin{array}{l}\text { Small towns around Etna, } \\
\text { Sicily *\# }\end{array}$ & volcanic & $11-14$ & Both & 0.03 & & 0.01 & 0.10 & & 0.30 & 0.10 & 0.40 & & & 0.20 & Tamburo et al. [36] \\
\hline Sardinia, Italy & mining areas & $11-13$ & Both & 3.60 & & 3.60 & 0.70 & & 1.60 & 4.90 & 13.10 & & & 1.20 & Varrica et al. [37] \\
\hline $\begin{array}{l}\text { Alcalá de Henares, } \\
\text { Madrid, Spain }\end{array}$ & urban & $6-9$ & Both & ND & ND & 0.52 & 0.66 & 1.10 & 0.30 & 0.42 & 1.48 & 1.29 & ND & 0.44 & Peña-Fernández et al. [46] \\
\hline Flix, Spain & urban & $12-13$ & Boys & 0.08 & 0.004 & ND & & 0.47 & 0.13 & 0.26 & 0.80 & 0.23 & ND & 0.19 & Torrente et al. [47] \\
\hline Flix, Spain & urban & $12-13$ & Girls & 0.09 & 0.004 & 0.02 & & 0.47 & 0.19 & 0.53 & 0.59 & 0.33 & ND & 0.17 & Torrente et al. [47] \\
\hline
\end{tabular}

$\mathrm{ND}=$ Non-detected. ${ }^{*}$ Metal concentration is expressed as median. \# Metal levels were measured in scalp hair. 


\section{Conclusions}

The presence of $\mathrm{Cd}, \mathrm{Pb}, \mathrm{Hg}, \mathrm{Ni}, \mathrm{Sn}, \mathrm{Mn}, \mathrm{Cr}$ and $\mathrm{V}$ in hair of schoolchildren living near the HWI of Constantí (Tarragona County, Catalonia, Spain) was confirmed in this study. Some significant differences according to the sex were noted, while $\mathrm{Hg}$ was the only metal with significant differences according to the zone of residence of the schoolchildren. The levels of $\mathrm{Cr}$ and $\mathrm{Pb}$ decreased since 1998, when the biomonitoring program was started and despite $\mathrm{Mn}, \mathrm{Ni}, \mathrm{Pb}$ and $\mathrm{Sn}$ showed higher levels in 2017 when compared to some previous surveys, their concentrations were even lower than those reported in recent literature. The present results indicate that the current emissions of metals by the HWI do not pose direct health risks of immediate concern. The follow-up monitoring program should be continued in order to assure there are no changes in human exposure to trace elements in the vicinity of the HWI.

Author Contributions: Conceptualization, M.S. and J.L.D.; methodology, M.M. (Montse Mari) and M.M. (Montse Marquès); software, M.M. (Montse Mari); validation, R.E. and M.N.; formal analysis, R.E. and M.M. (Montse Marquès); investigation, R.E., M.M. (Montse Mari), M.S., J.L.D. and M.N.; resources, M.M. (Montse Mari); data curation, R.E.; writing—original draft preparation, R.E.; writing—review and editing, M.N.; visualization, M.S.; supervision; project administration, M.M. (Montse Marquès) and J.L.D; funding acquisition, J.L.D.

Funding: This study was funded by Sarpi Constantí SL, Catalonia, Spain.

Acknowledgments: The authors appreciate the technical assistance of Anabel Díez for the sampling and the analytical treatment, as well all the schoolchildren and their families, who provided all the samples.

Conflicts of Interest: The authors declare no conflict of interest.

\section{References}

1. Schuhmacher, M.; Granero, S.; Llobet, J.M.; de Kok, H.A.; Domingo, J.L. Assessment of baseline levels of $\mathrm{PCDD} / \mathrm{F}$ in soils in the neighbourhood of a new hazardous waste incinerator in Catalonia, Spain. Chemosphere 1997, 35, 1947-1958. [CrossRef]

2. Llobet, J.M.; Schuhmacher, M.; Domingo, J.L. Observations on metal trends in soil and vegetation samples collected in the vicinity of a hazardous waste incinerator under construction (1996-1998). Toxicol. Environ. Chem. 2000, 77, 119-129. [CrossRef]

3. Schuhmacher, M.; Domingo, J.L.; Llobet, J.M.; Lindström, G.; Wingfors, H. Dioxin and dibenzofuran concentrations in adipose tissue of a general population from Tarragona, Spain. Chemosphere 1999, 38, 2475-2487. [CrossRef]

4. Schuhmacher, M.; Domingo, J.L.; Llobet, J.M.; Lindström, G.; Wingfors, H. Dioxin and dibenzofuran concentrations in blood of a general population from Tarragona, Spain. Chemosphere 1999, 38, 1123-1133. [CrossRef]

5. Schuhmacher, M.; Domingo, J.L.; Llobet, J.M.; Kiviranta, H.; Vartiainen, T. PCDD/F concentrations in milk of nonoccupationally exposed women living in southern Catalonia, Spain. Chemosphere 1999, 38, 995-1004. [CrossRef]

6. Granero, S.; Llobet, J.M.; Schuhmacher, M.; Corbella, J.; Domingo, J.L. Biological monitoring of environmental pollution and human exposure to metals in Tarragona, Spain. I. Trace Elem. Electrolytes 1998, 15, 39-43.

7. Llobet, J.M.; Granero, S.; Schuhmacher, M.; Corbella, J.; Domingo, J.L. Biological monitoring of environmental pollution and human exposure to metals in Tarragona, Spain. II. Levels in autopsy tissues. Trace Elem. Electrolytes 1998, 15, 44-49.

8. Llobet, J.M.; Granero, S.; Torres, A.; Schuhmacher, M.; Domingo, J.L. Biological monitoring of environmental pollution and human exposure to metals in Tarragona, Spain. III. Blood levels. Trace Elem. Electrolytes 1998, 15, 76-80.

9. Domingo, J.L.; Schuhmacher, M.; Granero, S.; Llobet, J.M. PCDDs and PCDFs in food samples from Catalonia, Spain. An assessment of dietary intake. Chemosphere 1999, 38, 3517-3528. [CrossRef]

10. Llobet, J.M.; Granero, S.; Schuhmacher, M.; Corbella, J.; Domingo, J.L. Biological monitoring of environmental pollution and human exposure to metals in Tarragona, Spain. IV. Estimation of the dietary intake. Trace Elem. Electrolytes 1998, 15, 136-141. 
11. Skalny, A.V.; Zhukovskaya, E.V.; Kireeva, G.N.; Skalnaya, M.G.; Grabeklis, A.R.; Radysh, I.V.; Shakieva, R.A.; Nikonorov, A.A.; Tinkov, A.A. Whole blood and hair trace elements and minerals in children living in metal-polluted area near copper smelter in Karabash, Chelyabinsk region, Russia. Environ. Sci. Pollut. Res. 2018, 25, 2014-2020. [CrossRef] [PubMed]

12. Linares, V.; Perelló, G.; Nadal, M.; Gómez-Catalán, J.; Llobet, J.M.; Domingo, J.L. Environmental versus dietary exposure to POPs and metals: A probabilistic assessment of human health risks. J. Environ. Monit. 2010, 12, 681-688. [CrossRef] [PubMed]

13. Sakakibara, M.; Sera, K. Current Mercury Exposure from Artisanal and Small-Scale Gold Mining in Bombana, Southeast Sulawesi, Indonesia-Future Significant Health Risks. Toxics 2017, 5, 7. [CrossRef]

14. Evrenoglou, L.; Partsinevelou, S.A.; Stamatis, P.; Lazaris, A.; Patsouris, E.; Kotampasi, C.; Nicolopoulou-Stamati, P. Children exposure to trace levels of heavy metals at the north zone of Kifissos River. Sci. Total Environ. 2013, 443, 650-661. [CrossRef] [PubMed]

15. Castaño, A.; Pedraza-Díaz, S.; Cañas, A.I.; Pérez-Gómez, B.; Ramos, J.J.; Bartolomé, M.; Pärt, P.; Soto, E.P.; Motas, M.; Navarro, C.; et al. Mercury levels in blood, urine and hair in a nation-wide sample of Spanish adults. Sci. Total Environ. 2019, 670, 262-270. [CrossRef]

16. Jiang, F.; Ren, B.; Hursthouse, A.; Deng, R.; Wang, Z. Distribution, source identification and ecological-health risks of potentially toxic elements (PTEs) in soil of thallium mine area (southwestern Guizhou, China). Environ. Sci. Pollut. Res. 2019, 26, 16556-16567. [CrossRef]

17. Quansah, R.; Armah, F.A.; Essumang, D.K.; Luginaah, I.; Clarke, E.; Marfoh, K.; Cobbina, S.J.; Nketiah-Amponsah, E.; Namujju, P.B.; Obiri, S.; et al. Association of Arsenic with Adverse Pregnancy Outcomes/Infant Mortality: A Systematic Review and Meta-Analysis. Environ. Health Perspect. 2015, 123, 412-421. [CrossRef]

18. Bartrem, C.; Tirima, S.; Von Lindern, I.; Von Braun, M.; Worrell, M.C.; Mohammad Anka, S.; Abdullahi, A.; Moller, G. Unknown risk: Co-exposure to lead and other heavy metals among children living in small-scale mining communities in Zamfara State, Nigeria. Int. J. Environ. Health Res. 2014, 24, 304-319. [CrossRef]

19. Anyanwu, B.; Ezejiofor, A.; Igweze, Z.; Orisakwe, O. Heavy Metal Mixture Exposure and Effects in Developing Nations: An Update. Toxics 2018, 6, 65. [CrossRef]

20. Marquès, M.; Nadal, M.; Díaz-Ferrero, J.; Schuhmacher, M.; Domingo, J.L. Concentrations of PCDD/Fs in the neighborhood of a hazardous waste incinerator: Human health risks. Environ. Sci. Pollut. Res. 2018, 25, 26470-26481. [CrossRef]

21. Domingo, J.L.; García, F.; Nadal, M.; Schuhmacher, M. Autopsy tissues as biological monitors of human exposure to environmental pollutants. A case study: Concentrations of metals and PCDD/Fs in subjects living near a hazardous waste incinerator. Environ. Res. 2017, 154, 269-274. [CrossRef] [PubMed]

22. Schuhmacher, M.; Mari, M.; Nadal, M.; Domingo, J.L. Concentrations of dioxins and furans in breast milk of women living near a hazardous waste incinerator in Catalonia, Spain. Environ. Int. 2019, 125, 334-341. [CrossRef] [PubMed]

23. Nadal, M.; Mari, M.; Schuhmacher, M.; Domingo, J.L. Monitoring dioxins and furans in plasma of individuals living near a hazardous waste incinerator: Temporal trend after 20 years. Environ. Res. 2019, 173, 207-211. [CrossRef] [PubMed]

24. Nadal, M.; García, F.; Schuhmacher, M.; Domingo, J.L. Metals in biological tissues of the population living near a hazardous waste incinerator in Catalonia, Spain: Two decades of follow-up. Environ. Res. 2019, 176, 108578. [CrossRef]

25. Chojnacka, K.; Michalak, I.; Zielińska, A.; Górecka, H.; Górecki, H. Inter-relationship between elements in human hair: The effect of gender. Ecotoxicol. Environ. Saf. 2010, 73, 2022-2028. [CrossRef] [PubMed]

26. Molina-Villalba, I.; Lacasaña, M.; Rodríguez-Barranco, M.; Hernández, A.F.; Gonzalez-Alzaga, B.; Aguilar-Garduño, C.; Gil, F. Biomonitoring of arsenic, cadmium, lead, manganese and mercury in urine and hair of children living near mining and industrial areas. Chemosphere 2015, 124, 83-91. [CrossRef]

27. Jursa, T.; Stein, C.; Smith, D. Determinants of Hair Manganese, Lead, Cadmium and Arsenic Levels in Environmentally Exposed Children. Toxics 2018, 6, 19. [CrossRef] [PubMed]

28. Taraškevičius, R.; Zinkutè, R.; Gedminienè, L.; Stankevičius, Ž. Hair geochemical composition of children from Vilnius kindergartens as an indicator of environmental conditions. Environ. Geochem. Health 2018, 40, 1817-1840. [CrossRef] 
29. Vella, C.; Attard, E. Consumption of Minerals, Toxic Metals and Hydroxymethylfurfural: Analysis of Infant Foods and Formulae. Toxics 2019, 7, 33. [CrossRef]

30. Xie, W.; Peng, C.; Wang, H.; Chen, W. Health risk assessment of trace metals in various environmental media, crops and human hair from a mining affected area. Int. J. Environ. Res. Public Health 2017, 14, 1595. [CrossRef]

31. Nadal, M.; Bocio, A.; Schuhmacher, M.; Domingo, J.L. Monitoring metals in the population living in the vicinity of a hazardous waste incinerator: Levels in hair of school children. Biol. Trace Elem. Res. 2005, 104, 203-213. [CrossRef]

32. Ferré-Huguet, N.; Nadal, M.; Schuhmacher, M.; Domingo, J.L. Monitoring Metals in Blood and Hair of the Population Living Near a Hazardous Waste Incinerator: Temporal Trend. Biol. Trace Elem. Res. 2009, 128, 191-199. [CrossRef] [PubMed]

33. Martorell, I.; Nadal, M.; Vilavert, L.; Garcia, F.; Schuhmacher, M.; Domingo, J.L. Concentrations of trace elements in the hair of children living near a hazardous waste incinerator in Catalonia, Spain. Trace Elem. Electrolytes 2015, 32, 43-51. [CrossRef]

34. Semenova, I.N.; Rafikova, Y.S.; Khasanova, R.F.; Suyundukov, Y.T. Analysis of metal content in soils near abandoned mines of Bashkir Trans-Urals and in the hair of children living in this territory. J. Trace Elem. Med. Biol. 2018, 50, 664-670. [CrossRef] [PubMed]

35. Drobyshev, E.J.; Solovyev, N.D.; Ivanenko, N.B.; Kombarova, M.Y.; Ganeev, A.A. Trace element biomonitoring in hair of school children from a polluted area by sector field inductively coupled plasmamass spectrometry. J. Trace Elem. Med. Biol. 2017, 39, 14-20. [CrossRef] [PubMed]

36. Tamburo, E.; Varrica, D.; Dongarrà, G. Gender as a key factor in trace metal and metalloid content of human scalp hair. A multi-site study. Sci. Total Environ. 2016, 573, 996-1002. [CrossRef]

37. Varrica, D.; Tamburo, E.; Milia, N.; Vallascas, E.; Cortimiglia, V.; De Giudici, G.; Dongarrà, G.; Sanna, E.; Monna, F.; Losno, R. Metals and metalloids in hair samples of children living near the abandoned mine sites of Sulcis-Inglesiente (Sardinia, Italy). Environ. Res. 2014, 134, 366-374. [CrossRef]

38. Sanna, E.; Floris, G.; Vallascas, E. Town and gender effects on hair lead levels in children from three Sardinian Towns (Italy) with different environmental backgrounds. Biol. Trace Elem. Res. 2008, 124, 52-59. [CrossRef]

39. Tamburo, E.; Varrica, D.; Dongarrà, G. Coverage intervals for trace elements in human scalp hair are site specific. Environ. Toxicol. Pharmacol. 2015, 39, 70-76. [CrossRef]

40. Giné-Bordonaba, J.; Vilavert, L.; Nadal, M.; Schuhmacher, M.; Domingo, J.L. Monitoring environmental levels of trace elements near a hazardous waste incinerator human health risks after a decade of regular operations. Biol. Trace Elem. Res. 2011, 144, 1419-1429. [CrossRef]

41. Vilavert, L.; Nadal, M.; Schuhmacher, M.; Domingo, J.L. Concentrations of metals in soils in the neighborhood of a hazardous waste incinerator: Assessment of the temporal trends. Biol. Trace Elem. Res. 2012, 149, 435-442. [CrossRef] [PubMed]

42. González, N.; Calderón, J.; Rúbies, A.; Timoner, I.; Castell, V.; Domingo, J.L.; Nadal, M. Dietary intake of arsenic, cadmium, mercury and lead by the population of Catalonia, Spain: Analysis of the temporal trend. Food Chem. Toxicol. 2019, 132, 110721. [CrossRef] [PubMed]

43. Schuhmacher, M.; Bellés, M.; Rico, A.; Domingo, J.L.; Corbella, J. Impact of reduction of lead in gasoline on the blood and hair lead levels in the population of Tarragona Province, Spain, 1990-1995. Sci. Total Environ. 1996, 184, 203-209. [CrossRef]

44. Domingo, J.L.; Perelló, G.; Giné Bordonaba, J. Dietary intake of metals by the population of Tarragona County (Catalonia, Spain): Results from a duplicate diet study. Biol. Trace Elem. Res. 2012, 146, 420-425. [CrossRef] [PubMed]

45. González, N.; Marquès, M.; Nadal, M.; Domingo, J.L. Levels of PCDD/Fs in foodstuffs in Tarragona County (Catalonia, Spain): Spectacular decrease in the dietary intake of PCDD/Fs in the last 20 years. Food Chem. Toxicol. 2018, 121, 109-114. [CrossRef] [PubMed] 
46. Peña-Fernández, A.; González-Muñoz, M.J.; Lobo-Bedmar, M.C. Evaluating the effect of age and area of residence in the metal and metalloid contents in human hair and urban topsoils. Environ. Sci. Pollut. Res. 2016, 23, 21299-21312. [CrossRef]

47. Torrente, M.; Gascon, M.; Vrijheid, M.; Sunyer, J.; Forns, J.; Domingo, J.; Nadal, M. Levels of Metals in Hair in Childhood: Preliminary Associations with Neuropsychological Behaviors. Toxics 2013, 2, 1-16. [CrossRef]

(C) 2019 by the authors. Licensee MDPI, Basel, Switzerland. This article is an open access article distributed under the terms and conditions of the Creative Commons Attribution (CC BY) license (http://creativecommons.org/licenses/by/4.0/). 